\title{
An Empirical Study on Family Financial Behavior
}

\author{
Wida Purwidianti \\ Economic and Business Faculty, Universitas Muhammadiyah Purwokerto \\ Student in Doctoral Program Management Science, Economic and Business Faculty, \\ Jenderal Soedirman University Purwokerto \\ widapurwidianti@ump.ac.id
}

\begin{abstract}
The purpose of this study is to examine the effects of financial literacy (knowledge), financial experience, locus of control, gender and family members towards financial behavior. Although study in financial behavior mayvary, the number of studies that investigate the relationship between financial behavior and family member variable is limited. Research data were collected by interviewing head of family in Purwokerto, Indonesia. The results revealed that financial knowledge, financial experience, and locus of control partially have a positive influence on financial behavior. This study was unable to provide empirical evidence of the effect of gender and the number of family members on financial behavior.
\end{abstract}

Keywords: financial knowledge, financial experience, locus of control, gender

\section{INTRODUCTION}

The study of behavior in finance at the present time is growing very rapidly. Behavioral finance takes human factors into account, through perceptions, individual evaluations and emotional elements involved in taking and making investment decisions [1].Research on financial behavior has been done a lot but research on family financial behavior is still in limited number. Family finance research is very interesting and important to study because this study discusses the importance of financial management in the family.

Finance literacy is strongly associated with the behavior, habits and influence of external factors [2]. Meanwhile, [3] defines financial literacy as knowledge to manage finance in order to live more prosperous in the future. Research on the relationship between the trend of financial behavior and private pension funds in Turkey found evidence that perceptions and attitudes toward risk, emotional intelligence, basic and advanced financial knowledge affect the preferences of someone pension fund [4].

Arifin[5] shows that there is positive and significant influence from Financial Knowledge to Financial Behavior, which means that the greater the knowledge possessed by an individual, the better the financial behavior. Financial knowledge was significantly positive related to financial management behavior [6].

Yulianti, Norma \& Silvy [7] stated that good and correct financial decisions are needed to increase income, manage expenses, pay taxes so that family financial management becomes more proper. Positive childhood experiences about managing finances, the social environment, and attitudes toward savings play the role of financial management in future family behavior.

The experience of managing finance can also be a consideration in financial decision making as well as investment planning [8]. Someone's consideration of risk and return faced will affect the return of decisions in planning the investment. The experience of managing finances is not solely to have investment products but can take advantage of investment products.

Research on the relationship between CEO's personality and corporate debt proves that the company's progress is consistent with CEO's behavior in choosing leverage. The study found that the CEO's personal behavior could explain the company's financial behavior from the companies they manage [9].

Lubis et al. [10], states that financial behavior will be influenced by several factors: financial literacy and financial experience. The results of [11] found evidence that financial experience has a significant effect on financial behavior whereas financial knowledge has no significant effect on financial behavior. On the other hand, the results of the study [12] found evidence that financial knowledge has a significant relationship to financial behavior.

Locus of control is a variable that will affect financial behavior. [13] States that the locus of control is a someone's perspective on an event whether he or she can or cannot control the events that happen to him. Results of the study [14] and [15] found evidence of locus of control having a significant positive effect on financial behavior.[5] Shows that there is positive and significant influence from Locus of Control to Financial Behavior, which means that the higher the individual's locus of control, the better the financial behavior. [6] External locus of control had negative effect on financial management behavior.

The results of the study [16] suggest that gender influenced the investment behavior. The results [17] also found evidence of social demographic variables having a significant effect on investment management behavior. Bigan et al. [18] find evidence that a male presence increases theprobability of selecting a higher risk investment. 
This research develops the results of existing research by developing variables that have not been studied. The variable added in this study is family members. According to [19], the number of family members will affect the number of needs that must be met by a family. The study found evidence of differences in family financial behavior with different numbers of members.Hereafter,the hypotheses for this study will be stated below.

H1: Financial knowledge is positively related to financial behavior

$\mathrm{H} 2$ : Financial experience is positively related to financial behavior

H3 : Locus of control is positively related to financial behavior

$\mathrm{H} 4$ : Gender is positively related to financial behavior

H5 : Family member is positively related to financial behavior

\section{METHOD}

This study used a sample of household heads residing in Banyumas Regency, Central Java Province, Indonesia. A total of 85 heads of households were sampled for this study. Financial knowledge was measured using an interval scale from"not knowing" (score 0) to "know" (score 1). Question indicators used include knowledge of profit sharing and credits, knowledge of profit sharing,etc. Financial experience was measured on a Likert scale of 1 to 5 with respondents' experience indicators investing in banking, capital markets, etc.

Locus of control used a Likert scale of 1 to 5.The question indicators are the financial decision-making ability, the feelings to live the life, etc. Family members variable was measured by counting the number of family members who are underthe responsibility of the head of the family.

Dependent variable in this research is financial behavior. The scale used to measure the financial behavior variable is the Likert scale of 1 to 5 . The question indicatorsare the on time bill payment, the preparation of financial drafts for the future, the money allowance for savings, etc.

\section{RESULT}

Descriptive statistics of respondents showed that $63.5 \%$ of respondents were female and $36.5 \%$ were male. Respondents who have the smallest number of family members are a person and the highest are 7 people with the following details: a person is $1.2 \%, 2$ people are $14.1 \%, 3$ are $31.8 \%, 4$ are $25.9 \% 5$ are $14.1 \%, 6$ are $8.2 \%$ and 7 are $4.7 \%$. In terms of age of respondents, 10 people (11.8\%) age below 30 years, 19 people $(22.4 \%)$ age $30-$ 40 years and over 40 years are 56 people $(65,(\%)$. In addition, 38 people $(44.7 \%)$ hold below high school degree, 42 people $(49.4 \%)$ hold high school degree, and 5 people $(5.9 \%)$ hold undergraduate degree.

The result of the adjusted $\mathrm{R}^{2}$ test scored $50.6 \%$ and $\mathrm{F}$ test shows 18,201 score which is significant at level 0.00 . It meansfinancial literacy (knowledge), financial experience, locus of control, gender and family members simultaneously have effect on family financial behavior. Regression analysis result shows in Table 1.

Table:. Regression analysis

\begin{tabular}{|c|c|c|c|c|c|}
\hline \multirow{2}{*}{ Model } & \multicolumn{2}{|c|}{$\begin{array}{l}\text { Unstandardized } \\
\text { Coefficients }\end{array}$} & $\begin{array}{l}\text { Standardized } \\
\text { Coefficients }\end{array}$ & \multirow[b]{2}{*}{$\mathrm{t}$} & \multirow[b]{2}{*}{ Sig. } \\
\hline & B & $\begin{array}{l}\text { Std. } \\
\text { Error }\end{array}$ & Beta & & \\
\hline (Constant) & 9.239 & 1.591 & & 5.807 & .000 \\
\hline Knowledge & .234 & .119 & .220 & 1.971 & .052 \\
\hline Experience & .177 & .088 & .171 & 2.025 & .046 \\
\hline $\begin{array}{l}\text { Locus Of } \\
\text { Control }\end{array}$ & .205 & .051 & .441 & 3.991 & .000 \\
\hline Gender & .426 & .525 & .067 & .812 & .419 \\
\hline $\begin{array}{l}\text { Family } \\
\text { Number }\end{array}$ & -.234 & .180 & -.103 & $1.299^{-}$ & .198 \\
\hline
\end{tabular}

Table the financial knowledge variable $\mathrm{t}$ value is 1.971 and the significance value is $0.052, \mathrm{H} 1$ is supported. The financial experience variable $\mathrm{t}$ value is 2.025 and the significance value is $0.046, \mathrm{H} 2$ is supported. Meanwhile, the locus of control variable has $3.991 \mathrm{t}$ value and 0.00 significance value, $\mathrm{H} 3$ is supported. The Gender variable and family number variable shows 0.426 and $-0.234 \mathrm{t}$ value and 0.419 and 0.198 have significance value. This means H4 and H5 are not supported.

This study found evidence that financial knowledge can influence financial behavior. A high level of financial knowledge will affect the increasing of family financial behavior. The importance of strengthening the various aspects of the family is more recognized this day because as the smallest educational unit and interaction of the community, family is a place for reliable knowledge sharing, when optimally utilized [20]. Stated in [21], a high level of financial knowledge is positively correlated to higher income and savings. [22] Stated that individuals need basic financial knowledge and skills to effectively manage financial resources for the sake of their well-being. A person's competence to manage good finance is needed because of the increasing complexity of individual needs. Financial education in the family is focused on understanding the value of money to regulate the use of money.

The lack of education about personal financial knowledge is one of the obvious weakness in community education level. Education on finance is just a suggestion about saving, but it is not followed by other skills that will support a person's decisions in the financial field. The level of financial literacy of each person is also different. These differences lead to significant 
differences between individuals and other individuals in collecting both short-term and long-term assets.

The financial experience has a significant positive impact on financial behavior. A person's motivation to live better is to learn from experience. Experience can be learned from personal experience, friends, family or others who are more experienced so as to improve in the management, decision-making, and family investment planning. The results of the study [7] show that financial knowledge and financial experience affect the behavior of family financial investment planning.

Locus of control required by individuals for managing their finances. If individual self-control is good then the individual's financial behavior is also getting better. Study on self-control that predicts financial behavior and financial well-being showed that selfcontrol has a positive effect on financial behavior in general. In addition, individuals with good self-control have few issues related to financial problems and are more secure and confident in their current and future financial situation. This study has found that two constructs of optimistic and deliberative thinking also affect financial behavior and financial well-being [23]. This study is not in line with the study [24] which found that external locus of control has no significant effect on the behavior of individual financial management.

The result shows that gender and family members do not have a significant effect on family financial behavior. This study does not support the results of studies [12], [23], [18] and [16] which suggest that sex has a significant effect on financial behavior. This study was also inconsistent with the study [19] which found evidence of the number of family members influences investment behavior.

\section{CONCLUSION}

The results of this study provide evidence that financial knowledge, financial experience, and locus of control partially have a positive influence on financial behavior. Nevertheless, this study was unable to provide empirical evidence of the effect of gender and the number of family members on financial behavior.

One of the limitations of this study is the number of samples which still relatively small. Further research can be developed by enlarging the sample. There are several factors that influence financial behavior that have not been analyzed in research such as income level and tolerance to financial risk. Next, researchers should examine those factors.

\section{REFERENCES}

[1] Suciu, T. From the Classical Finance To the Behavioral Finance, (7), 80-89.(2015).

[2] Yushita, Aminta Novi. Pentingnya Literasi Keuangan Bagi Pengelolaan Keuangan Pribadi. Jurnal Nominal Volume VI nomer 1. (2017).

[3] Chen, H \&Volpe, RP. An Analysis of Personal Financial Literacy Among Collage Student. Financial Service Review Vol 7 No 2. (1998).
[4] Dogan, Moset. Testing The Relationship Between Behavioral Finance Trends And Private Pension Funds: An Application On The Bank Employees In Turkey. Haziran 2016; 18 (2); 543-564. (2016).

[5] Arifin, Agus Zainul. The Influence of Financial Knowledge, Control and Income on Individual Financial Behavior. European Research Studies Journal Volume XX, Issue 3A. (2017).

[6] Mien, Nguyen Thi Ngoc and Tran Phuong Thao. Proceedings of the Second Asia-Pacific Conference on Global Business, Economics, Finance and Social Sciences (AP15Vietnam Conference) ISBN: 978-1-63415-833-6. (2015).

[7] Yulianti, Norma \& Silvy Meliza. Sikap Pengelola Keuangan Dan Perilaku Perencanaan Investasi Keluarga Di Surabaya. Journal of Business and Banking Vol. 3 No 1, Mei (2013).

[8] Vitt, Lois A., Gwen M. Reichback, Jamie M. Kent, and Jurk K. Siegenthaler..Goodbye to Complacency: Financial Literacy Education in the U.S. 2000-2005. Middlesburg, VA: Institute forSocio-Financial Studies.(2005)

[9] Cronqvist, H., Makhija, A. K., \& Yonker, S. E. Behavioral consistency in corporate finance: $\mathrm{CEO}$ personal and corporate leverage. Journal of Financial Economics, 103(1), 20-40. https://doi.org/10.1016/j.jfineco.2011.08.005. (2012).

[10] Lubis, Arlina Nurbaety, Isfenti Sadalia, Khaira Amalia Fachrudin \& Juli Meliza. Perilaku Investor Keuangan. USU Press. Medan. (2013).

[11] Purwidianti, Wida \& Rina Mundjiyati. Analisis Pengaruh Pengalaman Keuangan Dan Tingkat Pendapatan Terhadap Perilaku Keuangan Keluarga Di Kecamatan Purwokerto Timur. Jurnal Benefit Vol 1 No 2. (2016).

[12] Andrew, Vincentius \& Linawati, Nanik. Hubungan Faktor Demografi dan Pengetahuan Keuangan Dengan Perilaku Keuangan Karyawan di Surabaya. Finesta Vol 2 No 2. (2014).

[13] Rotter, Julian B. Generalized Expectancies For External Versus Internal Control of Reinforcement. Psycologica Monograph Vol 8 N0 1. (1996).

[14] Kholilah, Naila Al \& Iramani, Rr. Studi Financial Management BehaviorPada Masyarakat Surabaya. Journal of Business and Banking Vol. 3 No 1, Mei(2013).

[15] Zainati, Nia. Pengaruh Locus of Control dan Sikap Keuangan yang Dimediasi Niat Terhadap Perilaku Pengelolaan Keuangan Keluarga. Artikel Ilmiah STIE Perbanas Surabaya. (2017).

[16] Putri, Ni made Dwiyana Rasuma dan Henny Rahyuda. Pengaruh Tingkat Financial Literacy dan Faktor Sosiodemografi Terhadap Perilaku Keputusan Investasi Individu. E Jurnal Fakultas Ekonomi dan Bisnis Universitas Udayana 6.9 : 3407-3434. (2017).

[17] Aminnatuzzahra. Persepsi Pengaruh Pengetahuan Keuangan, Sikap Keuangan, Sosial Demografi 
Terhadap Perilaku Keuangan Dalam Pengambilan Keputusan Investasi ( Studi Kasus Pada Mahasiswa Magister Manajemen Universitas Diponogoro). Jurnal Bisnis Strategi Vol 23 No 2.(2014).

[18] Bogan, Vicky L, David R Just and Chekitan S Dev. Team gender diversity and investment decisionmakingbehavior. Review of Behavioral Finance, Vol. 5 Iss 2 pp. 134 - 152. (2013).

[19] Jaflo, Felexia Davinci \& Wiwik Lestari. Perilaku Pengelolaan Keuangan Keluarga Dalam Perspektif Etnis dan Demografi. Artikel Ilmiah STIE Perbanas Surabaya. (2015).

[20] Masdar. Zaiful. Perencanaan Keuangan Komunitas Miskin di Perkampungan Vatutela. Jurnal Academica. Fisip Untad. Vol 3 No 01 Februari. (2011).

[21] Jorgesen, BL. Financial Literacy of Collage Student: Parental and Peer Influences. Thesis. Master of Science in Human Development Virginia. (2007).

[22] Shalahuddinta A, Susanti. Pengaruh Pendidikan Keuangan di Keluarga, Pengalaman Bekerja dan Pembelajaran di Perguruan Tinggi Terhadap Literasi Keuangan. Universitas Negeri Surabaya. (2014).

[23] Stromback, C., Lind, T., Skagerlund, K., Vastfjall, D., \& Tinghog, G. Does self-control predict financialbehavior and financial well-being? Journal of Behavioral and Experimental Finance, 14 , $30-$ 38.https://doi.org/10.1016/j.jbef.2017.04.002. (2017).

[24] Amanah, Ersha, Dadan Rahardian \& Aldila Iradianty. Pengaruh Financial Knowledge, Financial Attittude dan External Locul of Control Terhadap Personal Financial Management Behavior Pada Mahasiswa S1 Universitas Telkom. e Proceeding of Management Vol 3 No 2, August2016. (2016). 